\title{
Otomatisasi Pelayanan Binatu Berbasis Raspberry $P i$ Untuk Meningkatkan Efektivitas Dan Efisiensi Kegiatan Operasional Dan Pelayanan Binatu
}

\author{
Jurusan Teknik Elektro, Fakultas Teknologi Industri, Institut Teknologi Sepuluh Nopember (ITS) \\ Jl. Arief Rahman Hakim, Surabaya 60111 \\ e-mail:muhammad_rivai@ee.its.ac.id,habsyi12@mhs.ee.its.ac.id
}

\begin{abstract}
Abstrak-Bisnis binatu (laundry) atau bisnis jasa cuci pakaian merupakan bisnis yang menggiurkan saat sekarang ini. Proses layanan binatu umumnya terdiri dari pendaftaran, pengolahan, dan pengambilan pakaian. Proses ini memiliki banyak kekurangan yaitu pendaftaran manual tidak efektif dan efisien, pengolahan pakaian hanya diketahui oleh penyedia layanan binatu, dan pelanggan tidak mengetahui pakaian telah selesai. Ditengah persaingan bisnis yang begitu ketat, pelayanan konsumen merupakan suatu hal yang sangat penting. Penyedia jasa dituntut untuk berinovasi untuk menyediakan layanan jasa yang efektif dan efisien. Oleh karena itu pada penelitian ini merancang dan merealisasikan otomatisasi pelayanan binatu berbasis raspberry pi. Sistem ini menggunakan timbangan digital berbasis load cell, teknologi radio frequency identification (RFID) sebagai masukan data otomatis, Raspberry Pi sebagai pusat dari pengolahan basis data (database), dan webserver sebagai pusat informasi bagi pelanggan. Hasil penelitian menghasilkan beberapa kesimpulan. Timbangan digital memiliki eror rata-rata $0,88 \%$, metode RFID dapat memasukan data pelanggan secara otomatis dengan metode pengambilan nomor identitas jenis hex 8 digit, Raspberry $P i$ dapat mengakomodasi aplikasi yang efektif dan efisien untuk menyimpan data pelanggan secara otomatis dengan pemakaian CPU rata-rata 5\%, dan webserver yang digunakan dapat menyediakan informasi layanan binatu bagi pelanggan.
\end{abstract}

Kata Kunci-Binatu, Efektivitas, Efisiensi, Load Cell, RFID, Raspberry Pi, Webserver

\section{PENDAHULUAN}

Bisnis binatu (laundry) atau bisnis jasa cuci pakaian merupakan suatu aspek bisnis yang sangat menggiurkan saat sekarang ini. Proses layanan binatu dibagi beberapa tahap yaitu tahap pendaftaran cucian, pemrosesan pakaian, dan pengambilan pakaian. Umumnya pendaftaran dilakukan dengan cara manual. Pelanggan mengukur kuantitas pakaian. Kemudian petugas mencatat data yang terdiri dari kuantitas pakaian dan nama pelanggan. Lalu pakaian akan diproses oleh penyedia jasa binatu. Proses tersebut berupa cuci, jemur, dan setrika menurut permintaan pelanggan. Lalu pengambilan pakaian akan dilakukan oleh pelanggan beberapa hari kemudian [1].

Terdapat beberapa kekurangan yang ditemukan dari sistem layanan binatu model lama. Pertama, sistem pendaftaran manual tidak efektif dan efisien bagi pelanggan dan penyedia jasa. Pelanggan akan kehilangan waktu yang relatif banyak. Mulai dari menyebutkan nama, pencatatan tanggal sampai pengambilan bukti (receipt). Bagi penyedia jasa, cara manual ini juga akan menyulitkan untuk melakukan pendataan dan pembukuan. Kedua, bagian pemrosesan pakaian hanya diketahui oleh penyedia jasa saja. Pelanggan tidak mengetahui bagaimana kondisi pakaian. Dengan demikian pelanggan tidak bisa memperkirakan waktu proses layanan binatu akan selesai. Ketiga, pelanggan tidak dapat mengetahui dengan pasti waktu selesainya proses binatu. Hal tersebut membuat pelanggan tidak bisa menentukan pengambilan pakaian dengan sendirinya.

Ditengah persaingan bisnis yang begitu ketat, pelayanan terhadap konsumen merupakan suatu hal yang sangat penting. Penyedia jasa dituntut untuk berinovasi untuk menyediakan layanan jasa yang efektif dan efisien. Oleh karena itu, pada penelitian ini merancang dan merealisasikan otomatisasi pelayanan binatu berbasis Raspberry Pi. Sistem ini dilengkapi dengan timbangan digital berbasis sensor load cell dan teknologi radio frequency identification (RFID) untuk proses pendaftaran binatu. Sistem ini dilengkapi dengan aplikasi dan basis data (database) berbasis Raspberry Pi. Untuk penyedia informasi bagi pelanggan, sistem ini dilengkapi webserver yang dapat diakses langsung oleh pelanggan. Webserver berfungsi sebagai penyedia informasi bagi pelanggan. Informasi tersebut berupa riwayat binatu yang dilakukan pelanggan. Webserver juga menyediakan informasi proses binatu (cuci, jemur, setrika, selesai) yang sedang dilakukan penyedia jasa binatu. Sistem ini diharapkan bisa meningkatkan efektivitas dan efisiensi pelayanan sehingga memberi kepuasan yang lebih terhadap konsumen.

\section{TEORI PENUNJANG}

\section{A. Bisnis Binatu}

Bisnis binatu merupakan usaha penyedia jasa layanan dalam menangani masalah pakaian kotor. Layanan binatu telah menjadi gaya hidup modern dari masyarakat kota. Hal ini menimbulkan usaha atau gerai binatu terus tumbuh setiap tahunnya. Umunya proses layanan binatu di Indonesia memiliki prosedur yang sama. Pertama, pakaian kotor didaftarkan pelanggan ke layanan binatu. Pihak binatu membersihkan pakaian yang terdiri dari cuci, jemur, setrika, pengemasan. Terakhir, pelanggan mengambil pakaian dan membayar layanan binatu [1]. 


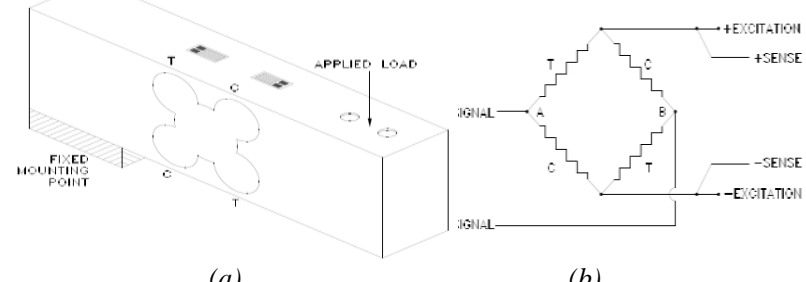

(a)

(b)

Gambar 1. Load Cell: (a) Komponen Strain Gauge dan (b) Jembatan Wheatstone

\section{B. Load Cell}

Load Cell terdiri dari suatu bahan elastik yang akan mengalami deformasi sesuai dengan gaya yang diterimanya, besarnya deformasi ini sebanding dengan besarnya gaya. Untuk mengukur besarnya defleksi deformasi bahan tersebut, salah satu cara yang populer adalah menggunakan strain gauge. Gambar 1.b menunjukkan load cell yang menggunakan strain gauge. Strain gauge $\mathrm{T}$ dan $\mathrm{C}$ dipasang sejajar di bagian load cell yang akan mengalami deformasi. Strain gauge T dan $\mathrm{C}$ dihubungkan menjadi jembatan wheatstone [2].

Umumnya load cell diberi resistor tambahan untuk mengompensasi pengaruh temperatur pada kinerja load cell. Tegangan eksitasi di aplikasikan pada sudut jembatan wheatstone (gambar 1.b) yang berlawanan dan sinyal output diukur melalui poin A dan B. Ketika tidak ada beban, semua strain gauge memiliki resistansi yang sama sehingga tidak ada perbedaan tegangan pada poin A dan B. Ketika beban ditambahkan, resistansi dari strain gauge akan berubah. Perubahan tersebut akan mengikuti rumus $C / T=T / C$. Hal ini akan menyebabkan ketidakseimbangan pada jembatan dan muncul perbedaan tegangan pada poin A dan B. Titik A dan B ini akan menjadi sinyal yang akan diolah mikrokontroller untuk mendapatkan nilai beban yang sebenarnya [3].

\section{Radio Frequency Identification (RFID)}

RFID membutuhkan dua buah perangkat, yaitu Tag dan Reader. RFID Tag Adalah sebuah alat yang melekat pada obyek yang akan diidentifikasi oleh RFID Reader. RFID Tag bersifat pasif (tanpa baterai). RFID Tag dapat berupa perangkat read-only yang berarti hanya dapat dibaca saja ataupun perangkat read-write yang berarti dapat dibaca dan ditulis ulang untuk update. RFID Tag mempunyai dua bagian penting, yaitu Integrated Circuit (IC) yang berfungsi menyimpan dan memproses informasi, modulasi dan demodulasi sinyal radio frequency (RF), mengambil tegangan DC yang dikirim dari RFID Reader melalui induksi, dan beberapa fungsi khusus lainya. Bagian lainnya adalah antena yang berfungsi menerima dan mengirim sinyal RF.

RFID reader adalah merupakan alat pembaca RFID Tag. Reader memiliki sistem pembaca aktif yang memancarkan sinyal interogator ke Tag dan menerima balasan autentikasi dari Tag. Sinyal interogator ini juga menginduksi Tag dan akhirnya menjadi sinyal DC yang menjadi sumber daya Tag Pasif [4].

\section{Raspberry Pi}

Raspberry $P i$, sering juga disingkat dengan nama Raspi, adalah komputer papan tunggal (Single Board Circuit /SBC) yang memiliki ukuran sebesar kartu kredit.

Raspberry $P i$ yang digunakan pada penelitian ini adalah Raspberry $P i 3$ model B. Raspberry Pi 3 merupakan jenis generasi ketiga. Raspberry $P i 3$ memiliki prosessor yang lebih kuat dari generasi sebelumnya yaitu 10 kali lebih cepat dari generasi pertama. Raspberry $P i$ ini dilengkapi dengan fitur Wireless LAN dan koneksi Bluetooth yang tidak dimiliki dua generasi sebelumnya [5].

\section{E. Lazarus}

Lazarus adalah sebuah IDE (Integrated Development Environment), lingkungan pengembangan perangkat lunak yang terintegrasi sehingga pembuatan software menjadi Rapid, dapat diselesai dalam waktu singkat. Lazarus bersifat open source, tersedia untuk banyak platform terutama Linux, Windows dan Macintosh. Bahasa pemrograman yang dijadikan landasan dalam Lazarus adalah Pascal [6].

\section{F. File Comma Separated Value (CSV)}

CSV sering digunakan untuk pertukaran data diantara aplikasi yang berbeda. CSV telah menjadi standar pseudo di seluruh industri teknologi informasi (IT) [7].

\section{G. XAMPP (Apache, MySQL, PHP, dan Perl)}

XAMPP merupakan perangkat lunak yang mendukung banyak sistem operasi dan merupakan kompilasi dari beberapa program. Fungsinya dalah sebagai server yang berdiri sendiri (localhost). Nama XAMPP sendiri merupakan singkatan dari $\mathrm{X}$ (empat sistem operasi apapun), Apache, MySQL, PHP, dan Perl. Dengan menginstall XAMPP maka tidak perlu lagi melakukan instalasi dan konfigurasi webserver Apache, $P H P$, dan $M y S Q L$ secara manual. XAMPP akan menginstalasi dan mengonfigurasikannya secara otomatis [8].

\section{PERANCANGAN SISTEM}

Perancangan otomasi sistem binatu terdiri dari beberapa bagian, yakni perancangan mekanik, perancangan perangkat lunak, perancangan user interface, dan perancangan webbrowser. Dalam perancangan semua sistem saling terkait antara satu dengan yang lainnya.

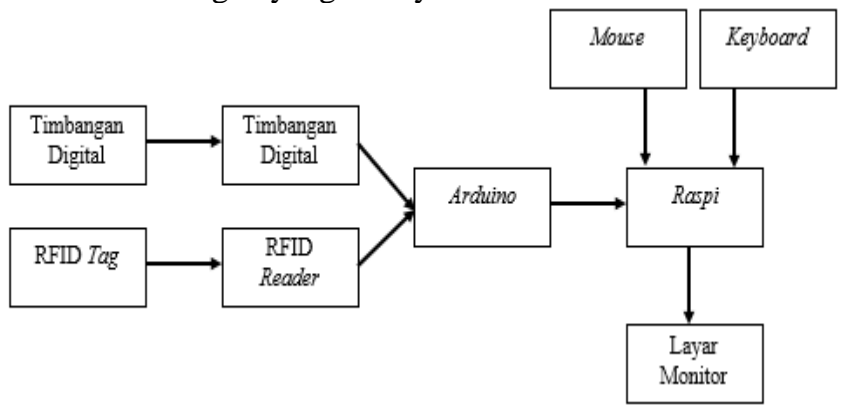

Gambar 2. Diagram Blok Sistem

Sistem dimulai dengan peletakan beban pakaian pada timbangan digital berbasis load cell. Data pembacaan nilai analog load cell akan dikonversi oleh modul HX711 menjadi 
nilai digital. Nilai digital akan diproses oleh arduino menjadi nilai kuantitas yang sesungguhnya dalam satuan $\mathrm{Kg}$. Setelah itu nomor identitas kartu RFID pelanggan akan dibaca melalui RFID reader. RFID reader akan mengirim data digital pembacaan ke arduino untuk diproses pembacaan nomornya. Nomor identitas memiliki format hex 8 karakter. Ketika nomor identitas telah didapatkan, arduino akan mengirimkan data kuantitas bebas pakaian serta identitas pelanggan ke raspi. Pada raspi terdapat suatu aplikasi dengan menggunakan software Lazarus. Aplikasi ini akan mencatat data masukan dari arduino. Data dari arduino akan diproses menjadi beberapa informasi yaitu kuantitas pakaian, nomor identitas pelanggan, nama pelanggan, biaya, waktu, dan jenis pelayanan binatu yang diinginkan. Data ini akan terus diperbarui seiring bertambahnya pelanggan pada hari tersebut. Setelah pelayanan hari tersebut selesai. Kumpulan data pelanggan yang didapatkan hari itu akan otomatis disimpan ke database berformat CSV pada memori raspi. Data harian yang telah didapatkan akan otomatis diperbarui ke dalam bentuk webserver yang bisa diakses online. Data pada web akan diperbarui untuk memperlihatkan proses binatu pakaian pelanggan.

Raspi dilengkapi dengan layar LCD, keyboard, dan mouse untuk memudahkan kegiatan operasional. Layar LCD digunakan untuk menampilkan aplikasi, mengolah database, dan mengatur isi pada webserver. LCD dan keyboard digunakan untuk memasukan input atau masukan yang diperlukan.

\section{A. Perancangan Perangkat Keras}

Perangkat keras pada penelitian ini adalah yaitu timbangan digital. Gambar 3 merupakan rancangan timbangan digital yang digunakan pada penelitian ini. Komponen utama timbangan terdiri dari 4, yaitu load cell, penyangga load cell, alas timbangan, dan kota beban timbangan diletakkan.

\section{B. Perancangan Elektrik}

Perangkat elektrik dalam penelitian ini meliputi rangkaian sensor timbangan, dan rangkaian RFID.

\section{- Rangkaian Sensor Timbangan}

Sensor load cell dihubungkan dengan modul HX711. Load cell mempunyai empat kabel penghubung yaitu VCC (kabel merah), Ground (kabel hitam), Data + (kabel putih), dan Data - (kabel hijau). Modul HX711 mempunyai empat pin sebagai masukkan untuk mikrokontroller (arduino). Pin-pin tersebut adalah Vcc, SCK, DT, dan Ground. Gambar 4.a merupakan rancangan rangkaian elektrik dari sensor timbangan

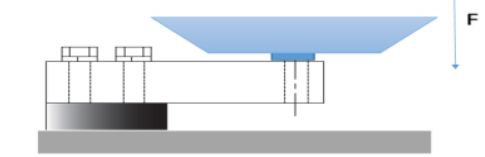

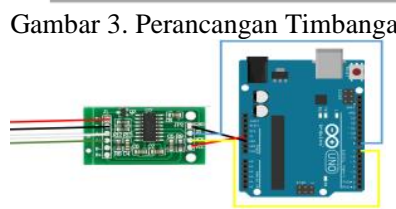

(a)

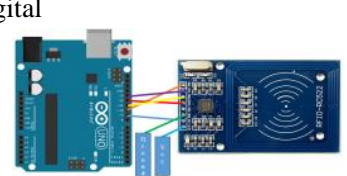

(b)
Gambar 4. Konfigurasi Arduino: (a) dengan Modul Sensor Timbangan dan (b) dengan modul RFID

\section{- Rangkaian RFID}

Untuk bekerja, modul RFID membutuhkan mikrokontroller sebagai pengolah data dan power supply untuk bekerja. Pada penelitian ini mikrokontroller yang digunakan adalah arduino sedangkan power supply menggunakan supply internal dari arduino sebesar 3.3V dan ground internal. Pin-pin yang harus dihubungkan dengan arduino adalah pin reset, SCK, Dout, MISO, MOSI, SDA(SS), dan CLK. Gambar 4.b merupakan rancangan RFID pada sistem.

\section{- Raspi dan Kelengkapan}

Raspi memiliki fungsi yaitu sebagai database, pusat human machine interface dan pusat pengendalian webserver. Raspi tidak mempunyai clock (real time clock) internal, sehingga ditambahkan clock eksternal. Konfigurasi RTC eksternal dengan raspi adalah dengan menghubungkan pin-pin RTC dengan pin GPIO raspi. Raspi membutuhkan power supply dengan tegangan 5 Volt dan arus $\pm 2.0 \mathrm{~A}$. Arus besar digunakan untuk menopang penggunaan mouse, keyboard, dan arduino uno.

\section{Perancangan Perangkat Lunak}

Perangkat lunak pada penelitian ini terdiri dari program timbangan digital, RFID, komunikasi serial arduino dengan raspi, human machine interface otomasi binatu, dan program webserver.

\section{- Program Arduino}

Diagram alir program arduino dijelaskan pada gambar 5 . Beban diukur dengan menggunakan timbangan digital. Nilai akan disimpan sementara dan ditampilkan pada LCD. Saat kartu RFID dimasukkan, data RFID dan data kuantitas beban akan dikirim melalui komunikasi serial ke raspi.

\section{- Program Raspi}

Diagram alir dari program aplikasi dijelaskan pada gambar 6. Ketika data dikirim dari arduino ke raspi, data dengan otomatis dimasukkan ke dalam tabel. Kemudian data akan otomatis disimpan pada database. Aplikasi membutuhkan program Input data ke tabel. Diagram alir dari program ini dijelaskan pada gambar 7. Prinsip kerja dari program ini terdiri dari beberapa proses. Proses ini terjadi ketika tombol "Start" ditekan. Masukan data didapatkan dari komunikasi serial. Setiap data akan dimasukan dengan metode CSV. Kolom berat dan ID akan diisi sesuai dengan data yang didapat dari arduino. Kolom nama diisi sesuai dengan ID yang dimasukkan. Prosesnya akan dijelaskan pada program memanggil database. Biaya akan diisi sesuai dengan layanan yang dipilih. Kolom tanggal dan waktu diisi sesuai dengan kondisi waktu proses. Terakhir, kolom layanan akan diisi manual oleh pengguna.Untuk mengatur pemasukan data dibutuhkan program pemanggilan database. Program ini dijelaskan pada gambar 8.a. Prinsip kerja dari program ini terdiri dari beberapa proses. Saat database dipanggil, program akan otomatis menuju alamat file CSV yang disimpan pada memori Raspberry Pi. Ketika data telah didapatkan data tersebut akan diubah menjadi matriks kolom imajiner. Proses memanggil ini digunakan saat mengisi kolom nama pada tabel, melihat database nama pelanggan dan menampilkan data harian pelanggan. Aplikasi ini memiliki fitur untuk menyimpan data ke database. Diagram alir dari program ini dijelaskan 
pada gambar 8.b. Prinsip kerja dari program ini terdiri dari beberapa proses. Data setiap baris akan dikonversi menjadi file CSV. Pembatas antar kolom akan memakai tanda baca titik koma(;). File akan disimpan dalam bentuk matriks kolom imajiner. Matriks tersebut akan dikonversi menjadi file CSV.

- Program Webserver

Diagram alir dari webserver dijelaskan pada gambar 9. Pelanggan memasukan nama ke dalam kotak yang disediakan pada web. Selanjutnya data pelanggan akan ditampilkan sesuai nama yang dimasukan.

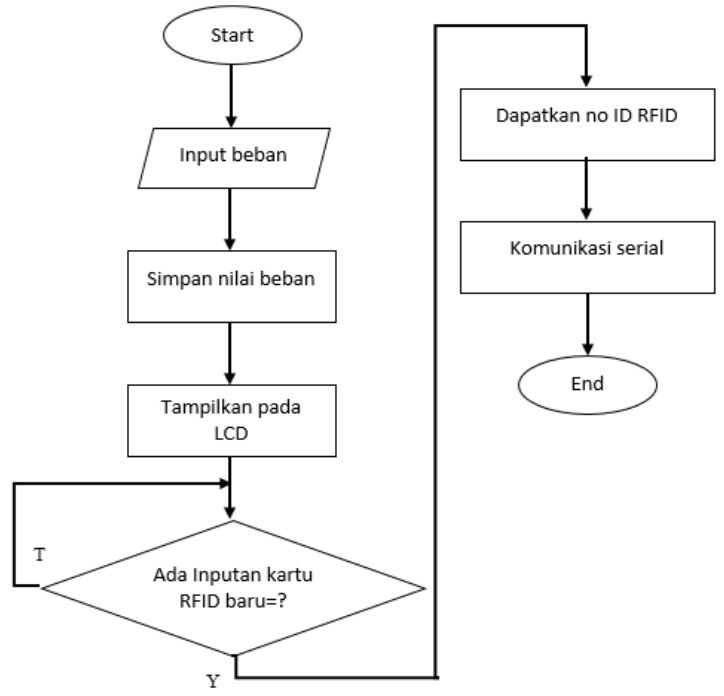

Gambar 5. Diagram Alir Program Arduino

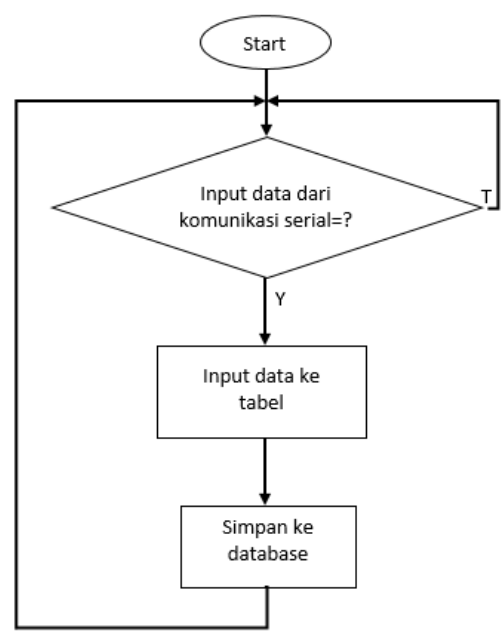

Gambar 6. Diagram Alir Program Aplikasi

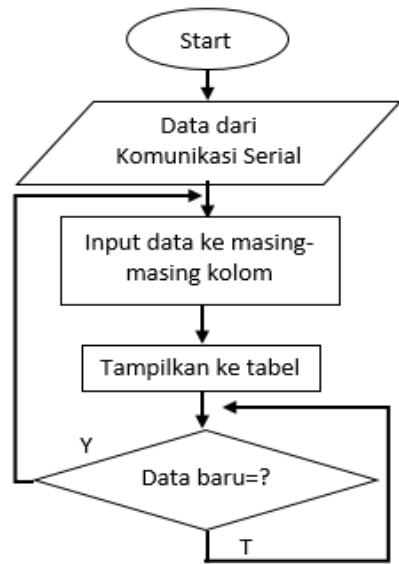

Gambar 7. Diagram Alir Program Input Data ke Tabel

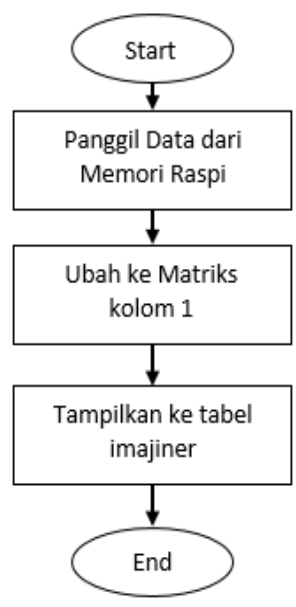

(a)

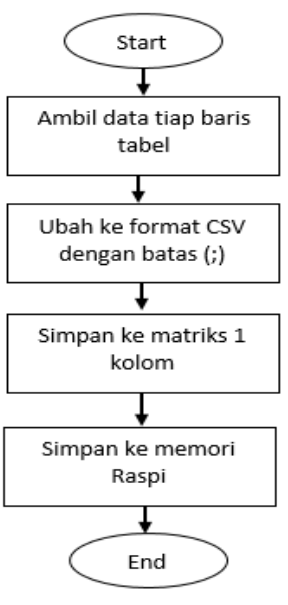

(b)

Gambar 8 Diagram Alir : (a) Import dan (b) Import Database

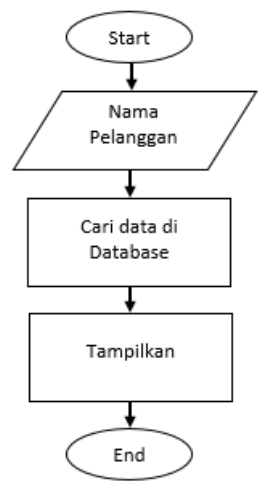

Gambar 9. Diagram Alir Webserver

\section{HASIL PENGUJIAN}

Pengujian pada sistem terdiri dari beberapa bagian yaitu pengujian perangkat keras, dan perangkat lunak. Tujuan dari pengujian ini untuk mendapatkan nilai dari sistem yang telah dirancang dan direalisasikan. 


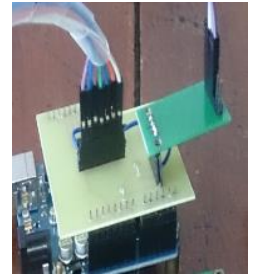

Gambar 10. Realisasi Timbangan Digital

\section{A. Pengujian Timbangan Digital}

Pengujian dilakukan dengan pengukuran 10 beban yang diambil secara acak (random). Hasil pengukuran dijelaskan pada tabel 1 dan gambar 11. Dari pengujian disimpulkan bahwa eror rata-rata dari timbangan digital sebesar $0.88 \%$.

\section{B. Pengujian dan Pengambilan Data RFID}

Pengujian RFID dilakukan dengan memeriksa apakah RFID reader dapat bekerja dengan baik. setelah RFID dapat bekerja dengan baik, dilakukan pengambilan data..Pengambilan data RFID dilakukan dengan meyimpan hasil pembacaan nomor identitas tag RFID. Data tag RFID diambil dari 10 tag RFID berbeda. Hasil contoh pengambilan data dijelaskan pada tabel 3.

Tabel 1.

Pengujian Timbangan Digital

\begin{tabular}{cccc}
\hline \hline Pengukuran & Nilai Sebenarnya & Nilai Pengukuran & Error \\
\hline 1 & $0,080 \mathrm{Kg}$ & $0,078 \mathrm{Kg}$ & $2,5 \%$ \\
2 & $0,174 \mathrm{Kg}$ & $0,170 \mathrm{Kg}$ & $2,29 \%$ \\
3 & $0,349 \mathrm{Kg}$ & $0,345 \mathrm{Kg}$ & $1,1 \%$ \\
4 & $0,354 \mathrm{Kg}$ & $0,351 \mathrm{Kg}$ & $0,9 \%$ \\
5 & $0,407 \mathrm{Kg}$ & $0,403 \mathrm{Kg}$ & $0,9 \%$ \\
6 & $0,860 \mathrm{Kg}$ & $0,856 \mathrm{Kg}$ & $0,5 \%$ \\
7 & $1,044 \mathrm{Kg}$ & $1,042 \mathrm{Kg}$ & $0,2 \%$ \\
8 & $1,925 \mathrm{Kg}$ & $1,923 \mathrm{Kg}$ & $0,1 \%$ \\
9 & $1,928 \mathrm{Kg}$ & $1,923 \mathrm{Kg}$ & $0,2 \%$ \\
10 & $4,676 \mathrm{Kg}$ & $4,675 \mathrm{Kg}$ & $0,02 \%$ \\
\hline \hline
\end{tabular}

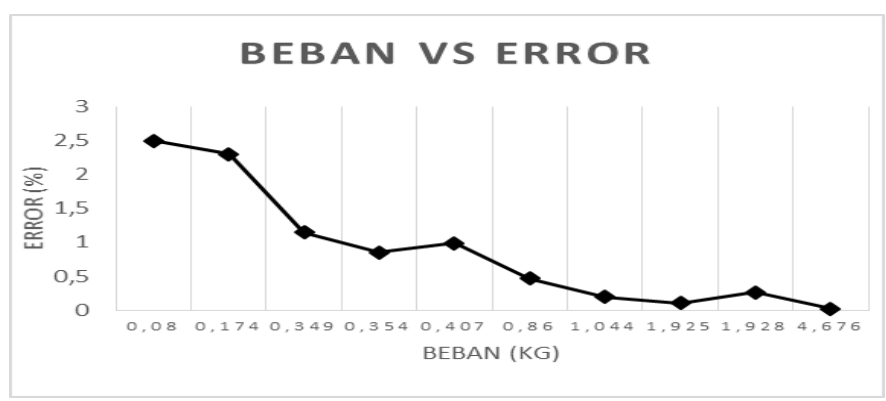

Gambar 11. Grafik Beban vs Eror

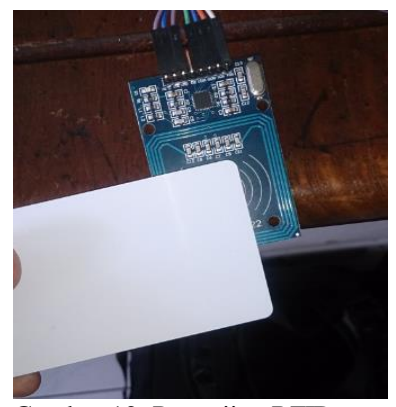

Gambar 12. Pengujian RFID
Tabel 2.

Pengambilan Data Tag RFID

\begin{tabular}{cc}
\hline \hline Identitas & Nama \\
\hline E31F8B00 & al \\
71CD43D5 & habsyi \\
594F3DD5 & fajar \\
6BB63DD5 & spongebob \\
\hline \hline
\end{tabular}

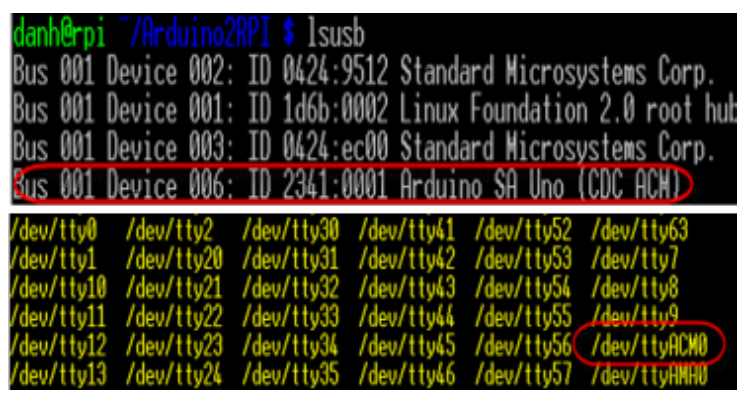

Gambar 13 Pengujian Komunikasi Serial

\section{Pengujian Aplikasi pada Raspberry Pi}

Pengujian aplikasi terdiri dari pengujian pengujian komunikasi serial, input data, pengujian penyimpanan data ke database, pengujian pemanggilan database dan pengujian webserver.

\section{- Pengujian Komunikasi Serial}

Pengujian pertama adalah pemeriksaan port arduino pada Raspberry Pi. Pengujian terbacanya usb arduino dilakukan dengan mengetikan lsusb pada command prompt. Pengujian letak port usb arduino dilakukan dengan mengetikkan $l s$ Idev/tty*. Gambar 13 Adalah hasil pengujian pemeriksaan port arduino pada raspberry pi. Port arduino yang terdeteksi oleh Raspberry Pi adalah /dev/ttyACMO. Port ini yang digunakan untuk program komunikasi serial antara arduino dengan Raspberry pi.

\section{- Pengujian Input Data}

Pengujian dilakukan dengan menjalankan aplikasi sesuai prosedur. Pengujian dilakukan seperti pada gambar 14. Pertama, data diterima melalui komunikasi serial. Data dari komunikasi serial dimasukkan sesuai kolom. Proses ini memasukkan ini (input) berjalan secara otomatis. Hasil pengujian dijelaskan pada gambar 15. Dari hasil pengujian dapat disimpulkan bahwa proses input data telah berfungsi dengan baik. Pengujian selanjutnya adalah melihat bagaimana pemakaian prosessor (CPU) saat aplikasi dijalankan. Hasil pengujian dijelaskan pada tabel 4. Dari pengujian dapat disimpulkan pemakaian CPU Raspberry Pi saat aplikasi dijalankan sebesar 5\%.

- Pengujian Penyimpanan Data ke Database

Pengujian simpan data ke database dilakukan dengan memeriksa apakah database telah tersimpan di memori dan dapat diakses dengan lembaran kerja Excell. Hasil pengujian dapat dijelaskan pada gambar 16. 


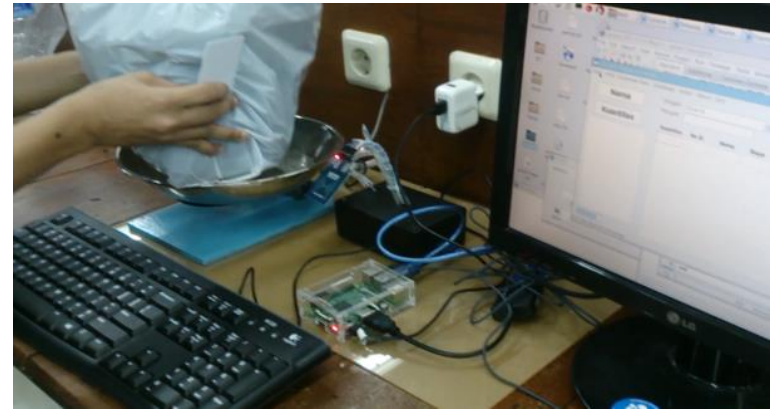

Gambar 14 Pengujian Aplikasi

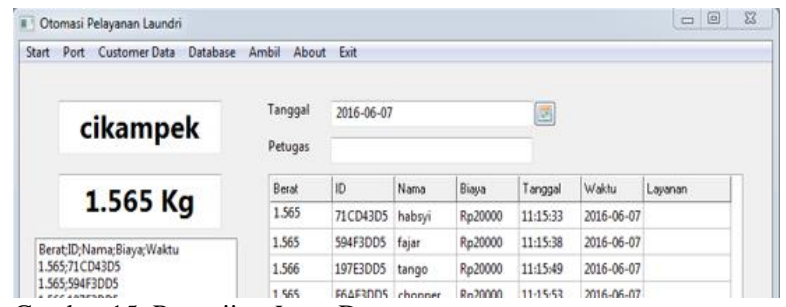

Gambar 15. Pengujian Input Data

Tabel 3.

Pengujian Pemakaian CPU Raspi

\begin{tabular}{cc}
\hline \hline Pengujian & Beban CPU \\
\hline 1 & $5 \%$ \\
2 & $4 \%$ \\
3 & $5 \%$ \\
4 & $5 \%$ \\
5 & $5 \%$ \\
\hline \hline
\end{tabular}

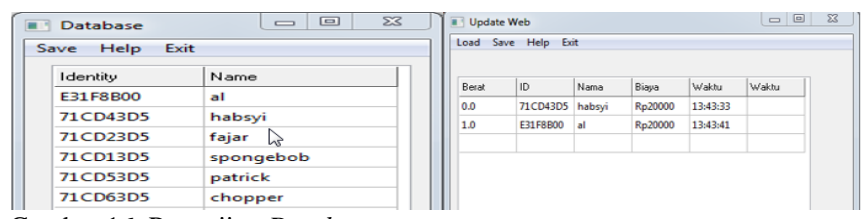

Gambar 16. Pengujian Database

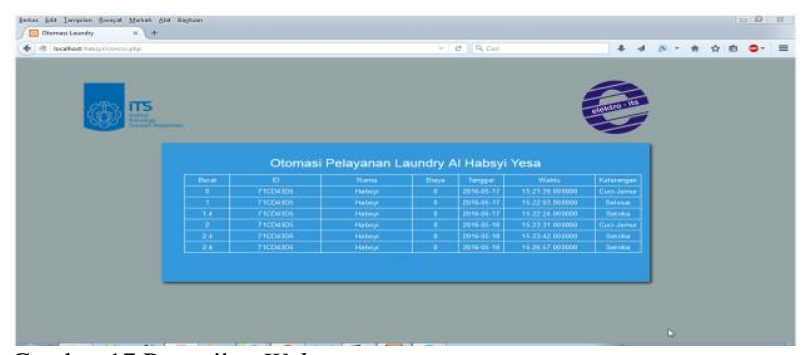

Gambar 17.Pengujian Webserver

\section{- Pengujian Webserver}

Webserver berfungsi untuk menampilkan data pelanggan melalui web. Pengujian dilakukan dengan menguji coba web dengan cara menginputkan nama pelanggan yang diinginkan. Setelah itu data pelanggan akan ditampilkan sesuai database yang berada pada memori. Hasil pengujian webserver (Gambar 17) menunjukkan webserver dapat digunakan sebagai penyedia layanan informasi bagi pelanggan.

\section{KESIMPULAN}

Pada penelitian ini telah dibuat dan dirancang sistem otomatisasi layanan binatu berbasis Raspberry Pi, timbangan digital menggunakan load cell, RFID sebagai kartu anggota dan webserver sebagai layanan informasi pelanggan. Berdasarkan pengujian yang telah dilakukakan, timbangan digital memiliki eror rata-rata $0,88 \%$. Metode RFID dapat memasukan data pelanggan secara otomatis dengan metode pengambilan nomor identitas jenis hex 8 digit. Raspberry dapat mengakomodasi aplikasi yang efektif dan efisien untuk menyimpan data pelanggan secara otomatis dengan pemakaian CPU rata-rata $5 \%$. Webserver yang digunakan dapat menyediakan informasi layanan binatu bagi pelanggan.

\section{DAFTAR PUSTAKA}

[1] Story, D., "Lessons Required for the Laundry Business of Tomorrow", ALM Education-Contact Hour Article and Quiz \#61, January, 2009.

[2] Load Cell Application and Test Guideline, Scale Manufacturers Assciation, Approved, April, 2010.

[3] Load Cell and Weigh Module Handbook, Rice Lake Weighing Systems, 2010.

[4] Kaur, M.., Sandhu, M., Mohan, N., dan Sandhu, P., S., "RFID Technology Principles, Advantages, Limitations \& Its Applications", International Journal of Computer and Electrical Engineering, Vol.3, No.1, February, 2011.

[5] Datasheets Raspberry Pi 3 Model B, Raspberry Pi.

[6] Garniart M., "Architecture of Lazarus". Available: http://www.blaisepascal.eu/

[7] Build Your Own Database Engine CSV Files, Available: http://www.festra.com/eng/les14.htm

[8] XAMPP Tutorial: How to Use XAMM to Run Your Own Web Server, September, 2013. Available : https://blog.udemy.com/xampp-tutorial/ 